\title{
The Identification of Persuasive Educational Message About Covid-19 Issue in New Media
}

\author{
${ }^{1}$ Mutia Rahmi Pratiwi, ${ }^{2}$ Kheyene Molekandella Boer, ${ }^{3}$ Teddy Dyatmika, ${ }^{4}$ Amida Yusriana

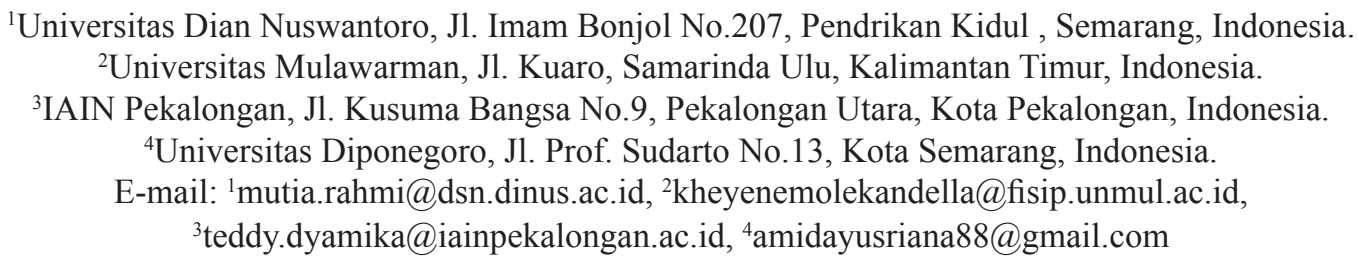

\begin{abstract}
Indonesia has becoming one of the countries with highest rate in Covid-19 transmission and part of 15 biggest countries in the world with highest death rate because of it. Various efforts has been conducting to persuade people such as delivering the Covid-19 education messages by new media TikTok. This research is a qualitative research with content analysis as the method. The object choosen are three video in new media TikTok that come from the point of view of the health workers, family of the health workers and society. The theory used is The Persuasive Theory. The results shows that the persuasive carried out through the research object used an evidence-based approach, using humor and based on diction. Based on diction is carried out from the side of the health worker family members. Based on the evidence is carried out from the point of view of people affected by the virus. The humor approach is carried out from the perspective of medical personnel. The message structure contained in the video object shows uniformity, including the presentation of messages consisting of one-sided, the order in which the message is presented using the climax flow and drawing conclusions that indicate the message is expressed or addressed directly.
\end{abstract}

Keywords: New Media, TikTok, Covid-19, Persuasive Communication

\section{INTRODUCTION}

Various impacts due to the corona virus disease (Covid-19) pandemic which has happened almost 1 year have became world health problems due to the rapid spread and the increasing number of casualties. Indonesia is one of the countries with the largest covid transmission rate in the world based on The Worldometers data. Indonesia is one of the top 15 countries in the world with a high mortality rate and the number of deaths reported up to April 2021 has reached 1,589,359 cases (https://www. worldometers.info/coronavirus/, 2021).

One of the significant impacts seen because of pandemic is the changing in daily behavior patterns. The term New Normal or new habit continues to be echoed by the government in form of $3 \mathrm{M}$ socialization, including: Wearing masks, washing hands and maintaining distance. These three simple ways can support to delay the spread and transmission of Covid-19. Habits that have became culture in Indonesia, such as gathering and sharing are suddenly have to turn into a distance guard and avoiding crowds. Those have been becoming serious psychological problem for Indonesians. It seems that the various messages of health education in various forms whether carried out directly or offline in the form of field work or through mass media and online are not easy to be immediately adopted in the community. Conflicts have been occurring from various levels of society, resulting in reports of the public's 
reluctance to enforce the use of masks when they are outside the home and the difficulty of maintaining distance when meeting their peers.

Studies related to health communication during the pandemic have been carried out by medical personnel and academia. Such as the study of doctor and patient health communication based on local wisdom conducted by Al Husain in 2020. The results showed that 5 doctors who were the research subjects applied strategic communication words or steps to patients who came to the hospital and this is relevant to Dramaturgy theory (Husain, 2020). The socialization process regarding the Adaptation of Health Assistance in the Pandemic Period with a Virtual Strategy was also carried out by Ismail, et al in 2020. Researchers said that PKBI Central Java used the Virtual Outreach strategy with a fairly effective evaluation because it required several steps, including: (1) Research/ field observations, (2) Adjusting the segmentation to the media used, and (3) Interactive persuasive communication (Amrizarois et al., 2020).

The government through the official covid19.go.id website has mapped several types of covid 19 risk educational material based on the audience segmentation including: the general public, people at risk, seniors, health workers, religious and community leaders, teachers and students, mothers and children, people who travels, entrepreneurs and business people. Educational materials designed for each segmentation are tailored according to the needs and conditions of the segmentation itself. The government also continues to strive to create various creative ways so that health messages can be well received in the community. In 2020, during the pandemic, there were several studies that discussed about the delivery of covid educational messages through various online media. Research has been carried out by Wardhani, et al in 2020 regarding education on the prevention of Covid-19 transmission through audio-visual learning media where education is carried out through the distribution of educational videos to children (Wardhani et al., 2020). The media plays a role in disseminating information originating from government policies about Covid-19 related to involving influencers to suppress the spread of Covid-19 among millennials (Boer et al., 2020). The Covid-19 educational media through the snake and ladder game media has been carried out by Arissanti, et al. In 2020 and the game was developed with an online play mode stage that allows matches to be played from various internet devices (Ariessanti et al., 2020). The next research that has been carried out related to covid-19 education is the research conducted by (Supriadi et al., 2020), examining the role of the West Java Regional Indonesian Broadcasting Commission in providing education about Covid-19.

The research emerged due to public panic about Covid-19. The results showed that the Indonesian Broadcasting Commission for West Java Regional recommended news broadcasting based on broadcasting ethics, implementing health protocols in broadcasting, and conducting media literacy in order to ward off hoax information that was disturbing the public. Research conducted by (Abdullah et al., 2020) examined the number of covid hoax news circulating in the community where the results show that the effects of covid hoax news have an impact on the economic and social aspects for society.

The research on TikTok is not a very new study. Previous research has been carried out from 2018 to 2020. In 2018, the results showed that TikTok was optimized as a medium for personal branding which was then 
uploaded on a personal Instagram page. TikTok optimization is carried out with attractive covers, good audio, hashtags, and involves the people closest to it (Susilowati, 2018). The use of TikTok in the scope of students can actually increase their creativity (Prianbodo, 2018). The main reason for someone to become a TikTok user is due to curiosity to follow trends and increasing their presence in cyberspace (Ayuningtias, 2019). The research findings show that the use of the TikTok application can improve mood due to the influence of music and the user's freedom to create according to their desires (Saputra et al., 2020). Based on the results of research references in the previous year, there has been no specific study about the form of persuasive communication that appears as the prevention educational message so it can be claimed that the research was carried out without any updating.

TikTok is a social media platform that is rapidly attracting users in Indonesia. This is supported by data acquisition from Sensor Tower, FIGURE 1 showing that TikTok is the most downloaded application in Indonesia in 2020.

Interestingly, the socialization carried out by the government is not only limited to direct socialization in the field but also social media optimization which is widely used so that it can have a wider impact on society. FIGURE 2 examples of covid 19 pandemic prevention socialization carried out by the government are the Ministry of Social Affairs and the Batu City Health Office. The following are TikTok video snippet uploaded on the YouTube page:

Apart from the government, the health companies also play a role in optimizing digital platforms. Alodokter. com as a digital health company in Indonesia also uses the TikTok digital platform to educate the public to recognize the symptoms of Covid-19, how to maintain the endurance and carry out physical distancing. FIGURE 3 Alodokter has been actively educating through TikTok Media since February 2020 and has 92.7 thousand followers and 740.5 likes (Kinanti, 2020).

Tik Tok also provides information sourced from the World Health Organization (WHO) regarding the number of Covid-19 cases in the world and various other health information. Tik Tok also collaborates with the International Red Cross Federation (IRFC), the Ministry of Health, the Ministry of Education and Culture to collaborate in providing sustainable education to the community. Doni Mardono as Chair of the Task Force for the Acceleration of Handling Covid-19 said that we will be able to fight this pandemic with collaboration from all parties. Tik Tok has shown a real example of collaboration not only in providing credible content for users but also contributing to Indonesian health workers (Wibowo, 2020).

Social campaigns related to Covid-19 conducted by various parties, both from the government and from the parties outside the government, are very massive. Whether it's through printed media, electronic media or internet media, which includes social media such as Facebook, Instagram, YouTube and Tik-Tok. The Covid-19 social campaign through social media is considered by most people to be important. This is because based on data from We Are Social, currently 175.4 million people in Indonesia are using the internet in 2020. This means that $64 \%$ of Indonesians already know and use the Internet from the total population in Indonesia of 272.1 million. After the data breakdown, the most significant usage was used by the community, such as social media users, where 160 million people use social media to fill their daily activities. These social media include Tik Tok, YouTube, 
Top Apps Worldwide for August 2020 by Downloads (Non-Game)

(D) SensorTower

\begin{tabular}{|c|c|c|}
\hline Overall Downloads & App Store Downloads & Google Play Downloads \\
\hline 1 J TikTok & 1 d) TikTok & 1 d) TikTok \\
\hline 2 zоOм & 2 zоом & 20 Snack Video \\
\hline 3 ff Facebook & 3 - YouTube & 3 \&f Facebook \\
\hline 4 (0) Instagram & 4 (으 Instagram & $4 \bigcirc$ Google Meet \\
\hline 5 (C) WhatsApp & 5 (C) WhatsApp & 50 ZOOM \\
\hline 6 Google Meet & 6 ff Facebook & 6 (2) Instagram \\
\hline $7 D$ Snack Video & $7 \simeq$ Messenger & 7 (C) WhatsApp \\
\hline $8 \sim$ Messenger & $8 \mathrm{M}$ Gmail & $8 \sim$ Messenger \\
\hline $9 \&$ Snapchat & $9 ?$ Google Maps & $9 \&$ Snapchat \\
\hline 10 (4) Telegram & $10 \mathbb{N}$ Netflix & $10 \bigodot \mathrm{MX}$ TakaTak \\
\hline
\end{tabular}

FIGURE 1. Most Downloaded Social Media

Source : https://www.worldometers.info/coronavirus/, 2020
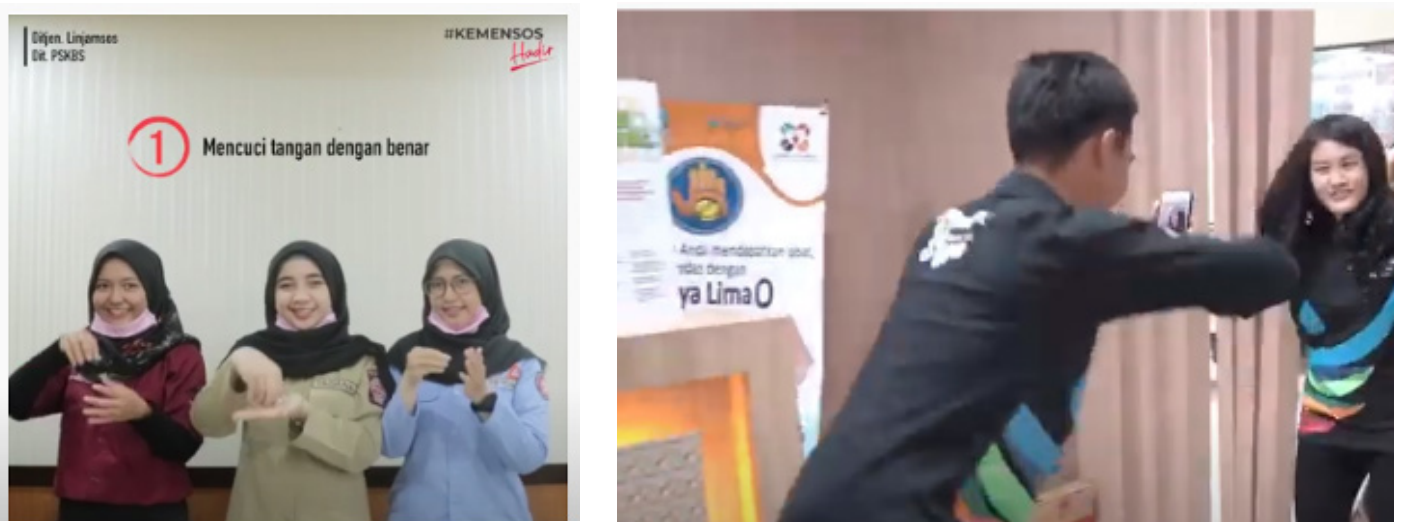

FIGURE 2. Video Footage of Covid Prevention Socialization through TikTok Source: Youtube.com

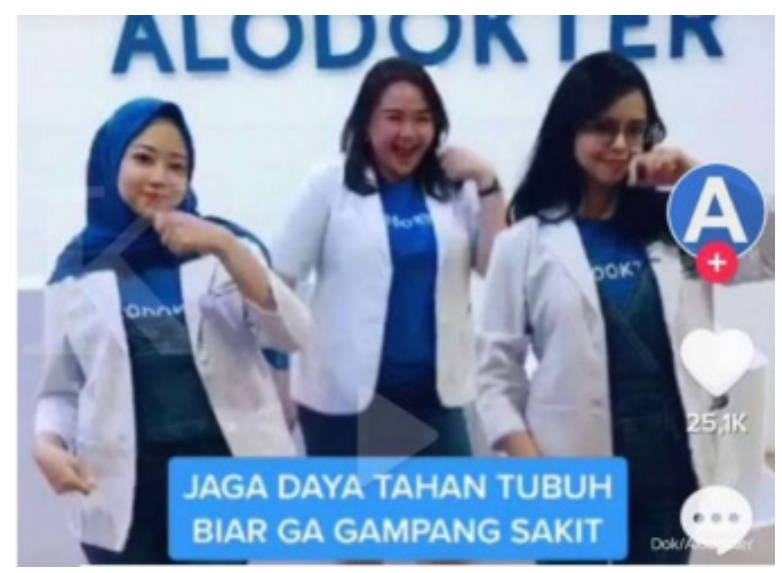

FIGURE 3. Educational Video Footage "Maintain Body Resistance" through TikTok Source : Kinanti, 2020 
Facebook, Instagram, Twitter, etc. (Haryanto, 2020). Based on the results of the research, millennials are able to receive information on social media, but sometimes there are still many of them who cannot report inaccurate information

According to (Dyatmika et al., 2020) someone's skill in receiving information about Covid 19 is in a good state. But they do not know how to report the negative information so it will not be widely spread. Besides, there is no punishment for someone eventhough they are reported in spreading false information (Bakhri et al., 2020).

Based on the data obtained and references to previous researches, it is necessary to have an in-depth study of socialization educational messages in reducing the number of Covid-19 sufferers through TikTok social media which currently has quite a lot of users in Indonesia. This research was conducted to seek the meaning of the presented messages about Covid 19 in Tik Tok Social Media.

\section{METHOD}

This research is the type of qualitative research with content analysis as the method. Content analysis is a method used to observe how researchers perceive the consistency of communication content qualitatively, the meaning of communication content, read various written symbols, and interpret the overall content of communication content (Bungin, 2007). There are three meanings of content analysis, such as: Content analysis is part of the existing written text, Content analysis is the main source of existing text and Content analysis looks at how the process of content emerges as a result of text analysis conducting for the content in a specified context. So it can be concluded that content never stands alone, so the analysis carried out on content is based on the context that is inherent in it (Rumata, 2017).

There are three content analysis approaches, they are the descriptive, explanative and predictive. Descriptive content analysis aims to describe the aspects, context and character of a message or text (Eriyanto, 2011).

\section{TikTok, New Media with Educational Content}

Technology that continues to develop in shaping the society to become both recipients and users of information. There has been changing in the communication process at the individual to group level. One of the manifestations of information is the ease of access to social media aimed at interaction and dissemination of information (Tosepu, 2018). Social media is a part of instant media that nowadays have several functions. Social media has a role and an impact on human lives that social media has benefits in the lives of every individual (Fardiah et al., 2020)such as Facebook, Twitter, Instagram, or mobile phone messages, such as WhatsApp, Telegram, etc. It is alarming if the information conveyed is inaccurate such as a hoax with a highly provocative title, leading the reader and recipient to obtain a negative opinion. For fighting hoaxes and preventing their negative impacts, the government has adequate legal protection named ITE Law. Apart from the legal product, the government also forms the National Cyber Institution. For example, in West Java, the government has formed West Java Clean Sweep Team (Saber. Social media is a communication medium that can create synchronization to pay attention to certain messages. The variety of forms of social media, from social networks to forums on digital pages, is now increasingly being used by the community (Ainiyah, 2018).

New media creates variety of virtual products containing information 
in any field, one of it is health. The trend of information consumption patterns through social media is now can be seen. Many people choose to meet their information needs through online media, one of it is social media. Thus, the presence of social media can also provide a large space for the government to enter through virtual campaigns, communicate health messages, one of which is by optimizing the Tik Tok application which is currently being loved by many people. The hope is that these messages reach the public and can change people's behavior patterns to comply with $3 \mathrm{M}$.

TikTok has been in Indonesia since 2018 but was eventually blocked by Kominfo on the grounds of its high negative content. The year of 2020 was the beginning of the rapid development of Tik Tok in Indonesia because this application was reopened by the Ministry of Communication and Informatics. Tik Tok has succeeded in gaining high users in Indonesia and has became part of popular culture, a culture that is liked by many people without being separated by social class or economic strata. So it cannot be avoided that the increasing number of users and more content is produced (Sorrells \& Sekimoto, 2016).

TikTok is the leading destination for short videos that provide many interesting features that spoil its users with various features such as: the Special Effects feature. Applications have been downloaded up to 740 million in 2019 and occupy the highest downloaded applications. This shows the high enthusiasm of the Indonesian people because it is a unique creative way (Devi, N. N. J. K., \& Dharmawan, N. K. S. (2021).

\section{Persuasive Communication Theory: Basic Concepts, Techniques, Approaches and Message Structure}

This research looks from the perspective of persuasive communication shown in the health messages with the theme of Covid-19 that appear in TikTok. Persuasive messages conveyed by communicators are intended to shape, strengthen, or changing the response of the recipient of the message (James B. Stiff $\&$ Paul A. Mongeau, 2016). Persuasive messages are received by a person through the activation of a person's psychological processes that involve three components, including: cognition, affection and convention, which eventually form behavior (Putri, 2016). There are three persuasive communication approaches: (1) Evidence-based approach. In this approach, data and facts are presented as a basis for arguments to strengthen the call. (2) A fear-based approach. In this approach, the sender of the message conveys a frightening fact or reality with the aim of the recipient of the message following the invitation that appears in the form of a persuasive message. (3)The approach is carried out using fun humor so that people are more interested in reading and the recipient of the message is easier to remember because there are positive emotional effects in the message. (4) A diction based approach, for example when the sender of the message using words that are easy to remember or are familiar and memorable which have positive or negative emotional effects (Burgon and Huffner, 2002).

Persuasion will always involve the goals and intentions of the communicator, using the media to achieve goals, and the recipient have the freedom to choose whether to accept or to reject the persuasive messages (Meredith, 2006). Persuasive message structure is related to how a message is presented to a wide audience. The three important points of the message structure are Message Sidedness (in terms of message), Order of Presentation and Conclusion Drawing. The following is an explanation of each 
structure: (1) Message Take sides consists of one sided and two sided. If the emphasis of the message is only addressed from the side of the sender of the message by highlighting the positive aspects of the message and there is no argumentation in the message that is contrary to a certain concept, it is a one-sided message. If the message is presented positively and negatively and contains pros and cons, it is a two-sided message (Kriyantono, 2010). (2) Order of Presentation includes Climax - Anticlimax and Recency Primary. The way of presenting messages by prioritizing arguments at the end of the message is a climax message while presenting messages with arguments delivered at the beginning is called anticlimax. Recency message structure is done by placing an interesting message at the end of a sentence and primacy occurs when a two-sided message is placed or delivered at the beginning of the sentence (Perloff, 2017). (3) Conclusion Drawing can be made explicitly (clearly and directly) or implicitly (subjective conclusions from each recipient of the message and its nature is indirect) (Kriyantono, 2010).

In 2020, Amalliah and Yunita conducted research on persuasive communication strategies in socializing the prevention of the Covid-19 virus in Palmerah, Jakarta. As a result, the education dissemination to prevent the spread of the virus was carried out with the strategy of the meaning, that is knowledge that could influence the behavior of the message recipient. The implementation of this strategy is to learn-feel-do-and make adjustments (Amalliah and Ria Yunita, 2020). The character of the communicator in conveying persuasive messages plays a very important role because it is part of the continuous process of communication. Persuasive communicators must have a self-ethos that refers to a person's selfesteem, including: cognition (knowledge), compassion, and conformity (Aw, 2019).

\section{RESULT AND DISCUSSION Research Object}

In this study, 3 videos related to Covid-19 were selected, taken from the side of the community and health workers. The following are the three videos on the TikTok page that are the objects of research:

\section{Video which tells about the struggle of father and son (lung specialists doctors) who are at the forefront of Covid-19 Handling}

This video in FIGURE 4 is uploaded on the TikTok page with the duration of 00.45 seconds. The following is a snippet of the TikTok video.

Here is the video narrative of the first object are: (a) My dad is a pulmonologist, he's 64 years old, (b) My brother learned a lot from dad to become a pulmonary doctor, (c) Those two are the front guards in this storm, (d) If Papa is tired and stressed, his condition will drop, (e)We are as the children often give advice: you can't be tired, you're old. Just cut down the schedule, (f) He said: I cannot neglect my patients. Please always pray for papa, (g) Apart from practicing, my brother is also active in educating the public in the media. Even though I just saw how tired his face was, (h) Eventhough his face is sad, there is still a bad netizen. The accusation of spreading fear or making big profits is behind the pandemic. Even though their lives are at stake; and (i) Wish them good health, friends.

\section{A video that tells about the struggles of Covid-19 patients while being treated at the Jakarta athlete guesthouse}

This video in FIGURE 5 was uploaded on the TikTok@ chaichaa25 account with the duration of 00.13 seconds. The following is a snippet of the 

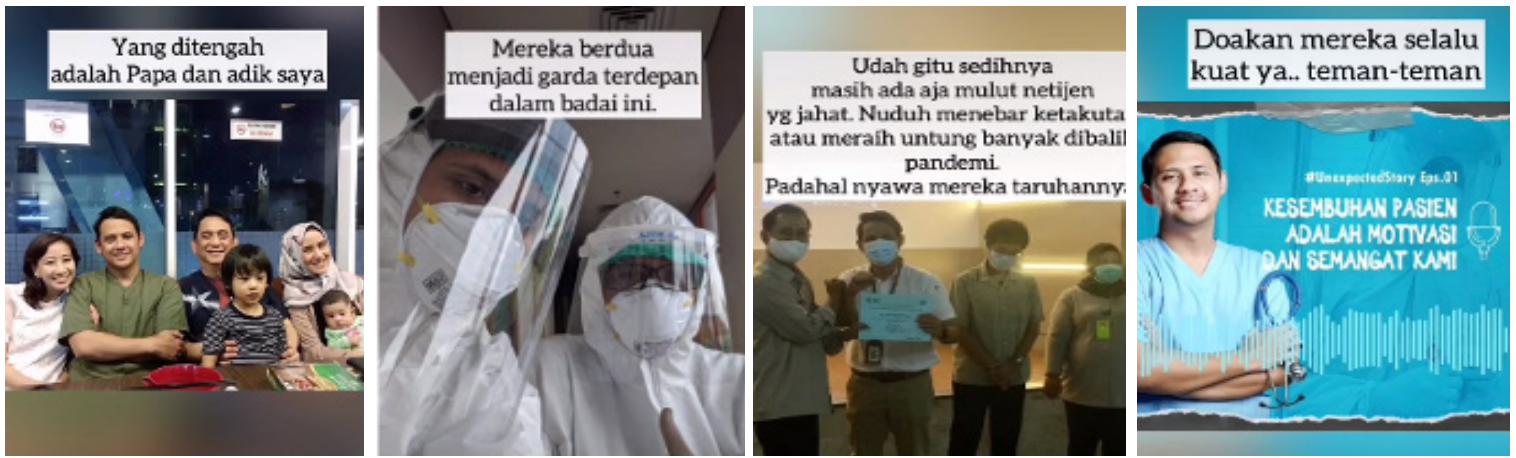

FIGURE 4. TikTok Video Visualization of Someone's father and brother as the First Research Object

TikTok video.

The video narration are (a) Morning Routine Activities for People Without Symptoms (OTG) Covid-19 at the Kemayoran Athlete Village, (b) The patient does light exercise by walking in the morning while maintaining distance, (c) Health workers participate in the morning exercise on foot, complete with personal protective equipments, (d) There are women smiling using masks outside the building under the hot sun, (e) Some people were seen sitting under the hot sun to sunbathe and holding cellphones and there were other patients drinking mineral water while sunbathing.

A video about steps that can be taken to avoid Covid-19 from the health worker's perspective. This video is delivered with humorous approach.

This video in FIGURE 6 was
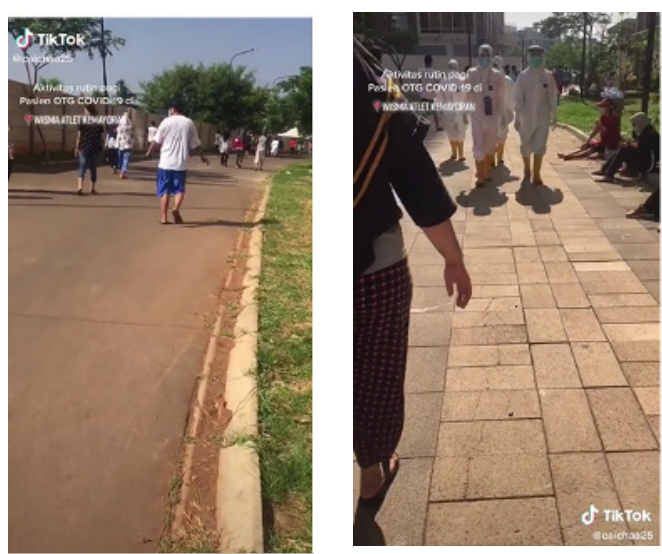

FIGURE 5. TikTok Video Visualization of Daily Activities of Covid-19 Sufferers as the Second Research Object
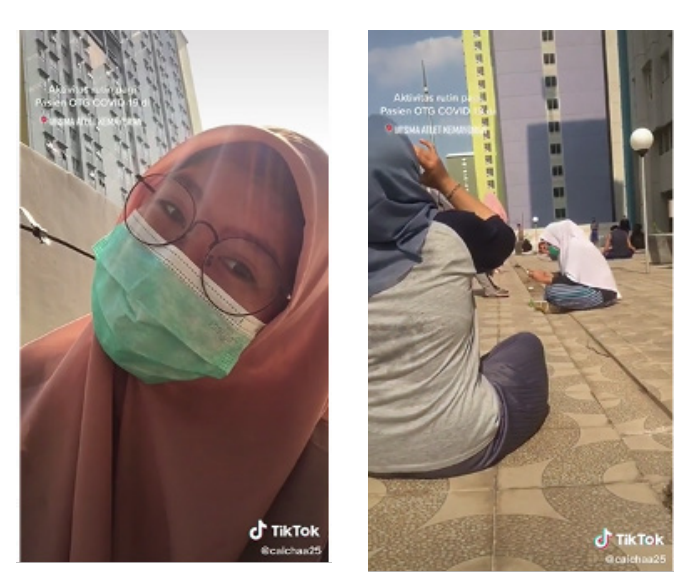

uploaded on the TikTok@leniparm13 page with duration of 00.15 seconds. The following is a snippet of the TikTok video.

The video narration are (a) Three health workers wear complete personal protective equipment while performing contemporary dance with the text on it "Health Protocol to Prevent Covid-19 Transmission Check !!!!., (b) The first message that appears is "always wear a mask and the emoticon symbol of wear a mask", (c) The second message that appears is "Always Wash Hands with Soap / Handsanitizer" and the medical personnel play a symbol of opening hands with water points and closed hands as if they are rubbing the soap, (d) The third message is "Apply Social Distancing X Keep X Distance", (e) Health workers change to personal protective equipment that looks more fashionable with colorful 

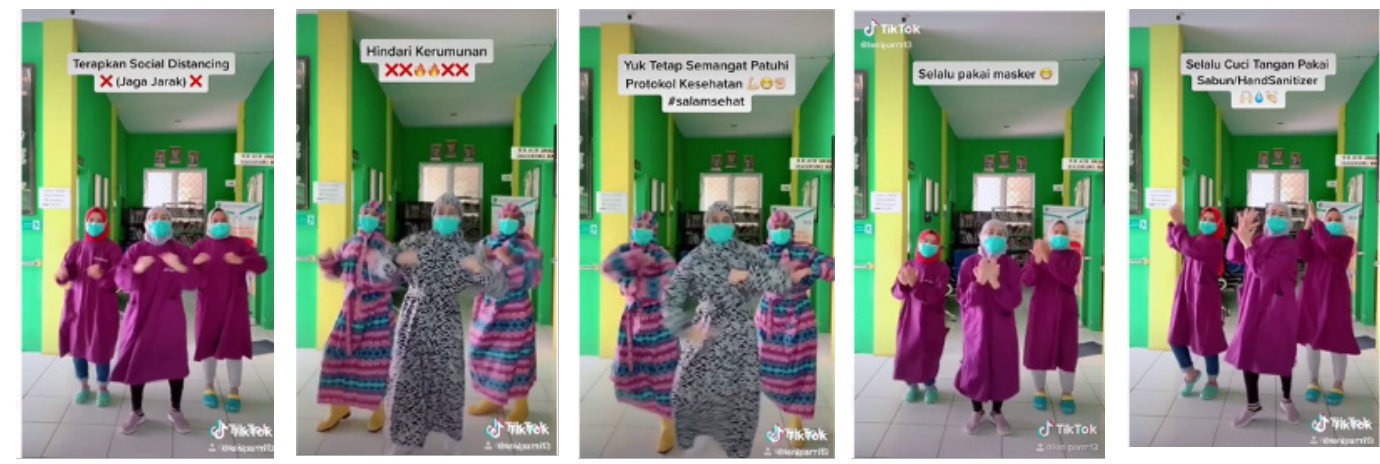

FIGURE 6. TikTok Video Visualization of The Health Worker in combating the Covid-19 as the third research object

motifs, (f) A fourth message appears, namely "Avoid the crowd XX, there is an image of the fire symbol XX", (g) The fifth or last message that appears is "Let's Keep the Spirit to obey the Health Protocol with a symbol of enthusiastic hand and emoticon of wearing a mask and \#salamsehat".

\section{Analysis of Research Findings Based on Persuasive Message Theory}

Content uploaded on social media has various purposes, from personal, group to corporate purposes. Content owners adjust the social media to be chosen with the expected goals (Pratiwi et al., 2019). In the first video, which tells about the struggle of a doctor, it is a persuasive message with a diction based approach where the sender of the message delivers a memorable message with emotional effects that can be obtained by the reader. The narrative that was conveyed repeatedly stirred the audience's emotions, here are some sentences that show the emotional side of the message sender:

"Alhamdulillah earlier this year my brother officially became a pulmonary doctor too, then the plague came, They both became the front guard in this storm. If Papa is tired and stressed, he will always drop. We are the children often remind him: you can't be tired, you're old . Just cut down the schedule. He said: I will end up neglect my patients. Please always pray for papa"

The paragraph above shows that the sender of the message stated that his family members were fighters in the vanguard. Often doctors ignore their interests to continue to carry out their obligations in caring for patients. The strength of the narrative of persuasion messages lies in who the communicator delivers the message. When a sense of empathy is grown from the closest person, namely the family, this is called transportation. According to (Green \& Clark, 2013), transportation or absorption is the success of persuasive messages through narrative that incorporate individual depth into the story presented.

From the perspective of the persuasive message structure, this message begins with a one-sided message, which is one-way from the sender of the message with the aim of conveying to the communicant that it is not easy for the family doctor as the vanguard to contribute as the supports system. From the family side, he has also tried to remind him of the age factor, but in the narrative it is conveyed that his father, who is a doctor, puts forward the interests of patients as those in need.

The next narrative contains about how the younger brother of the communicator as the sender of the message also struggles not only to care for patients in the hospital but also to 
provide Covid-19 educational message. Here is the narration that appears in the first object video:

"Apart from practicing, my brother is also active in educating the public in the media. Please just look at how tired his face looks $: \theta$, his face is already sad, there is still a bad netizen. The accusation of spreading fear or making big profits behind the pandemic. Even though their lives are at stake "

In terms of Order of Presentation (presentation of messages), the narrative that is conveyed is presented with an argument at the end and this presentation is called the Anticlimax. Tired statements that appear on faces but often get accusations that doctors are the most beneficiary during the Pandemic is the most painful thing for the family. This implies that there is disappointment that the family gets when the struggle of the family as a family doctor actually gets blasphemy from netizens whose identities are unknown clearly.

In the conclusion presentation structure, it is conveyed explicitly with the narrative sentence "Pray for them to be always healthy, friends," and supported by visual photos of family members who are doctors. According to (Farnas \& Gumelar, 2017), persuading someone can be done in an emotional and rational way. The use of rational persuasive is done by targeting the cognitive components of a person who are used as goals in influencing. The form of rational persuasion can be done by pouring out clear ideas or concepts. Emotional persuasion is carried out with the aim of touching the affection aspect by arousing one's sympathy and empathy aspects.

The presentation of a persuasive message in this video includes emotional persuasion. This can be seen from the choice of words used and supported by visuals and audio that inspire empathy and sympathy for the video audience. The delivery of the message on this video looks dramatic because the uploader is the younger brother and a child who loves his brother and father, where the two figures are doctors who treat Covid-19 patients. In this video, it describes the amount of affection and love from family members as the main support system so that it has an emotional impact on the audience rather than just delivering persuasive messages based on the latest data or rationally.

The choice of TikTok media as a medium for conveying messages can be interpreted that the possibility of TikTok users and the wider community who ultimately repost messages can be a separate force for medical personnel who are fighting the Covid-19 pandemic. The feedback obtained in the form of likes, comments, to the attitude of disseminating content is one proof that the media plays a very important role in meeting human communication needs. According to (Pratiwi, 2014), technology that continues to be created will help humans to meet basic communication needs, overcome distance in the form of limitations and facilitate the dissemination of information without time and space limitations.

In the second research object, the video contains messages without much narration but is supported by real pictures of situations that occur from the perpetrator's side. This content was created by a communicator who at that time was infected with the Covid-19 virus without symptoms or often called Orang Tanpa Gejala (OTG). According to (Abudi et al., 2020) the category of people without symptoms is those who have a history of direct or indirect contact with the patient and those who are included in the OTG category are those who are within 1 meter radius contact in the same room.

The communicator who at that time looked healthy and was not in the 
treatment room showed an optimistic face (part of non-verbal communication). In terms of the structure of the persuasive message, this message begins with a one-sided message, where it is one-way from the sender of the message with the aim of conveying to the communicant that during independent isolation you must stay cheerful and don't forget to do sports regularly, drink lots of water and also bask in the sun. The main message contained in the video is the routine that was conducted during the isolation and shared at the Jakarta Athlete House.

The messages that appear in the second video are mostly non-verbal messages. Persuasive communication can be displayed in verbal and non-verbal forms. Justisiani (2014), states that verbal communication is the delivery of messages that appear in oral and written forms in tangible form. Non-verbal communication is communication that is carried out using gestures, facial expressions, symbols and voice intonation. Verbal and non-verbal communication take place together and supports one another.

The video shows the patient doing light exercise on foot in the morning. Even though many people do exercise, they still follow health protocols by keeping their distance. The next message shows that health workers are also participating in walking sports while still using complete personal protective equipment. The next message is shown a woman as a communicator wears a medical mask with cheerful smile outside the building and under the hot sun. The next non-verbal message is that you can do other activities when you sunbathe in the morning, for example by playing on your cellphone and drinking more water.

In terms of Order of Presentation (presentation of messages), the narrative that is delivered is presented with an argument at the end and this presentation is called the climax. Where the communicator gives non-verbal messages under the hot sun and outside the building with a smiling face even though it is covered by a mask. The video gives a message to the communicant that even though he is being exposed to Covid-19, keep smiling and being happy which shows health from a psychological side.

In the third research object, the messages contain more narrative messages that are collaborated with contemporary dance and emoticon messages as reinforcement of the narrative message. In terms of persuasive message structure, this message begins with a onesided message, which is one-way from the sender of the message with the aim of conveying to the communicant that it is important to implement Health Protocols where at the beginning of the video there is a narrative "Health Protocols to Prevent Covid-19 Transmission Check !!!! which shows that currently implementing the Health Protocol is very important. In the message there is also a non-verbal symbol in the form of more than one warning sign indicating that the Health Committee cannot be bargained with in carrying out activities outside the home. The existence of a symbol of people shouting also reinforces the persuasive message conveyed in this video content.

The next narrative message is "always wear a mask and the emoticon symbol wear a mask" there are verbal and non-verbal messages that appear. The verbal message is the sentence always wears a mask while the non-verbal is a symbol of emoticon wearing a mask and the movements of dancers from health workers who cover their hands to the mouth and nose. The next narrative message is "Always Washing Hands with Soap or Hand Sanitizer", while the non-verbal message is a symbol of open hands, dripping water and closed hands like using soap plus movements such 
as someone washing their hands. The next narrative message is "Apply Social Distancing X Keeping X Distance" in the message there are 2 red crosses indicating that maintaining distance at this time is something very important. The next narrative message is "Avoid the crowd $\mathrm{XX}$, symbol 2 fires $\mathrm{XX}$ " is the verbal message to always avoid the crowd, while the non-verbal message is the fire symbol which shows that currently there are still many people crowding around which makes the communicator feel angry with the situation.

In conveying the message so that it can be accepted by the recipient or the wider community, thus serious attention is needed in packaging content. Information presented in the form of content must be tailored to the target communicant as the recipient of the message. The presentation of the content is done by strengthening the basic assumptions or the core of the message, which is supported by arguments that are both pro and contra or even a collaboration between the two. In order for the communicant as the recipient of the message to receive the message well, it needs to be done with five appeals, they are: appeals that are rational, emotional, causing fear, reward and motivate (Supratman, 2015). The narrative sentences that appear in this video show that the communicator persuades the communicant through rational and emotional appeal. This is indicated by the choice of words that emphasize such as: always, apply, avoid. Three words were shown at the beginning as a form of obligation that must be carried out by communicants in an effort to reduce the spread of Covid-19. Emotional appeals are shown by showing punctuation in bold, given an exclamation point, or adding symbols such as $\mathrm{X}$ (cross) and a fire sign that emphasizes the prohibition message.

In terms of Order of Presentation, the narrative that is delivered is presented with an argument at the end and this presentation is called the climax. Even though there are several message symbols that show stern warning signs at the end of the narrative, these stern warnings are always meant to protect each other between people so that the spread of Covid-19 does not get more and more severe.

In the conclusion presentation structure, it is conveyed explicitly with the narrative sentence "Let's Keep the Spirit to obey the Health Protocol with a symbol of enthusiastic hands and emoticon wearing a mask and \#salamsehat". This is an invitation sentence to all people that at this time do not become complacent. The community must continue to carry out proper health protocols when they do activities. According to (Susanti \& Yanti, 2020), the invitation sentence is part of the command sentence with the aim of inviting other parties to do something together according to the desired written down content and context. Invitation sentences usually use the word let's, come on, let's and various other forms of invitation words.

\section{CONCLUSION}

The educational message regarding covid-19 should be spread massively because Indonesia is one of the highest countries in the world for the level of covid-19 transmission and the 15 largest countries in the world with death rates due to covid-19. The lack of public awareness in implementing health protocols is one of the factors why Covid-19 has not been resolved in Indonesia. The use of social media as one of the media to provide covid-19 education and to persuade the public so that they are not complacent in their activities is quite effective. This study aims to identify persuasive messages contained in three objects of research where the messages consist of 
three points of view. The three points of view include the health worker, the health worker family and the community. The presentation of messages in the three research objects are also similar, such as the presentation of messages consisting of one-sided, the order of presenting messages that use a climax flow and drawing conclusions that indicate the message is expressed or addressed directly. Of the three videos, there is reinforcement of persuasive messages that are carried out not only verbally but also non-verbally, by using the facial expressions that strengthen verbal messages and displaying written text with symbols of prohibitions and commands. The narrative that appears in a persuasive message becomes an interesting object of research to be studied deeper for further research supported by the results of interviews that strengthen the findings of text analysis research.

\section{REFERENCES}

Abudi, R., Mokodompis, Y., \& Magulili, A. N. (2020). STIGMA TERHADAP ORANG POSITIF COVID-19. Jambura Journal of Health Sciences and Research. https://doi. org/10.35971/jjhsr.v2i2.6012

Abdullah, M. Q., Hayat, N., \& Rahman, A. (2020). The Agenda Setting of Corona: Analysis of the Corona Dissemination Impact on the Community. Mediator: Jurnal Komunikasi, 13(2), 141-155. https://doi.org/10.29313/mediator. v13i2.6302

Aida, N. R. (2020). 15 Negara dengan Kasus Kematian akibat Covid-19 Tertinggi, Indonesia Peringkat Berapa? https://www.kompas.com/ tren/read/2020/11/08/204500165/15negara-dengan-kasus-kematianakibat-covid-19-tertinggi-indonesia

Ainiyah, N. (2018). REMAJA MILLENIAL DAN MEDIA SOSIAL: MEDIA SOSIAL SEBAGAI MEDIA INFORMASI PENDIDIKAN BAGI
REMAJA MILLENIAL. 2(April), 221236.

Alodokter pilih TikTok untuk edukasi soal corona ke masyarakat. (2020). https://kesehatan.kontan.co.id/ news/alodokter-pilih-TikTok-untukedukasi-soal-corona-ke-masyarakat

Amalliah dan Ria Yunita. (2020). Strategi Komunikasi Persuasif Dalam Sosialisasi Pencegahan Penyebaran Virus Covid-19 Dilingkungan Warga Palmerah Jakarta Barat. 21(1), 1-9. http://journal.um-surabaya.ac.id/ index.php/JKM/article/view/2203

Amrizarois, I., Rofiq, M., Na'im, M. A., \& Rohman, I. A. (2020). Adaptasi Pendampingan Kesehatan Di Masa Pandemi Covid-19 Studi Strategi Virtual Outreach PKBI Kota Semarang. Jurnal Abdidas, 1(3), 157-164.

Ariessanti, H. D., Purwaningtyas, D. A., Soeparno, H., \& Alam, T. (2020). Adaptasi Strategi Gamifikasi Dalam Permainan Ular Tangga Online Sebagai Media Edukasi Covid-19. E-Jurnal JUSITI (Jurnal Sistem Informasi Dan Teknologi Informasi), 9(2), 174187. https://doi.org/10.36774/jusiti. v9i2.772

Aw, S. (2019). The failure of persuasive communication among social workers in mentoring street children. Jurnal Komunikasi: Malaysian Journal of Communication, 35(2), 161-175. https://doi.org/10.17576/ JKMJC-2019-3502-10

Ayuningtias, A. Y. (2019). Peran Media Sosial Aplikasi Tik Tok Dalam Perilaku Anak Remaja Tingkat SMA (Studi Fenomenologi Pemakai Aplikasi TikTok Dikalangan Anak Remaja). Universitas Pasundan.

Bakhri, S., Dyatmika, T., \& Kamal, M. R. (2020). Pengaruh Kemampuan Menggunakan Teknologi Komunikasi, Sosialisasi Media Pembelajaran Online, Dukungan Keluarga dan Pengajar Terhadap Keaktifan Mahasiswa di Masa Pandemi Covid-19. MEDIAKITA, 4(1). https:// doi.org/10.30762/mediakita.v4i1.2445

Boer, K. M., Pratiwi, M. R., \& Muna, N. (2020). Analisis Framing Pemberitaan 
Generasi Milenial dan Pemerintah Terkait Covid-19 di Media Online. Communicatus: Jurnal Ilmu Komunikasi. https://doi.org/10.15575/ cjik.v4i1.8277

Bungin, B. (2007). Analisis Data Penelitian Kualitatif. PT Raja Grafindo Persada.

Burgon and Huffner. (2002). Human Communication. Sage Publication.

Cegah Virus Corona, TikTok Gandeng Kreator Untuk Edukasi. (2020). https://lifestyle.bisnis.com/ $\mathrm{read} / 20200401 / 254 / 1220813 /$ CegahVirus-Corona-Tiktok-GandengKreator-Untuk-Edukasi

Devi, N. N. J. K., \& Dharmawan, N. K. S. (2021). PERLINDUNGAN HUKUM TERHADAP VIDEO KREATIF YANG DIUNGGAH PADA APLIKASI TIKTOK BERDASARKAN UNDANGUNDANG HAK CIPTA. Kertha Semaya: Journal Ilmu Hukum, 9(4), 715-724.

Dyatmika, T., Bakhri, S., \& Kamal, M. R. (2020). Kemampuan Siswa Dalam Menerima Informasi Hoax Covid-19. An-Nida: Jurnal Komunikasi ..., 12(2). https://ejournal.unisnu.ac.id/JKIN/ article/viewFile/1611/1484

Eriyanto. (2011). Analisis Isi: Pengantar Metodologi untuk Penelitian Ilmu Komunikasi dan Ilmu-Ilmu Sosial lainnya. Prenadamedia Group.

Fardiah, D., Rinawati, R., Darmawan, F., Abdul, R., \& Lucky, K. (2020). Media Literacy for Dissemination Anticipated Fake News on Social Media. Mediator: Jurnal Komunikasi, 13(2), 278-289. https://doi.org/10.29313/mediator. v13i2.6624

Farnas, A., \& Gumelar, G. (2017). Efektivitas Persuasif Melalui Narasi Dan Bukti Statistik Terhadap Pengambilan Keputusan Memilih Produk Handphone. Jppp - Jurnal Penelitian Dan Pengukuran Psikologi. https:// doi.org/10.21009/jppp.021.04

Green, M. C., \& Clark, J. L. (2013). Transportation into narrative worlds: Implications for entertainment media influences on tobacco use. In Addiction. https://doi.org/10.1111/ j.1360-0443.2012.04088.x

Husain, A. H. Al. (2020). Komunikasi Kesehatan Dokter dan Pasien Berbasis Kearifan Lokal Sipakatau di Masa Pandemi. Jurnal Ilmu Komunikasi, 18(2), 126. https://doi.org/10.31315/ jik.v18i2.3546

https://www.worldometers.info/coronavirus/, 2021. Covid 19 Coronavirus Pandemic Indonesia Sumbang Angka Unduhan TikTok Terbanyak di Dunia. (2020).

$\mathrm{h} \mathrm{t} \mathrm{tps://t} \mathrm{e} \mathrm{kno.kompas} \mathrm{.} \mathrm{com/}$ $\mathrm{read} / 2020 / 09 / 11 / 15010037 /$ indonesiasumbang-angka-unduhan-TikTokterbanyak-di-dunia

James B. Stiff, \& Paul A. Mongeau. (2016). Persuasive Communication. Guilford Press.

Justisiani, E. I. (2014). Persepsi Masyarakat Tentang Bentuk Komunikasi Verbal Dan Komunikasi Nonverbal Pada Pelayanan Rumah Sakit Umum Daerah Abdul Wahab Sjahranie Samarinda. EJurnal Ilmu Komunikasi.

Kriyantono, R. (2010). Teknik Praktis Riset Komunikasi: Disertasi Contoh Praktis Riset Media, Public Relation, Advertising, Komunikasi Organisasi, Komunikasi Pemasaran. Kencana.

Meredith, M. J. (2006). Book Review: Applying Communication Theory for Professional Life: A Practical Introduction. Business Communication Quarterly. https://doi. org/10.1177/108056990606900217

Perloff, R. M. (2017). The dynamics of persuasion: Communication and attitudes in the 21 st century. In The Dynamics of Persuasion: Communication and Attitudes in the Twenty-First Century. https://doi. org/10.4324/9781315657714

Pratiwi, M. R. (2014). Peran ICT bagi Organisasi Media Massa dan Budaya Masyarakat. Jurnal Komunikator.

Pratiwi, M. R., Hapsari, S. A., \& Yusriana, A. (2019). Refleksi Citra Universitas Dian Nuswantoro Melalui Unggahan di Akun@udinus_smg.Jurnal Penelitian Pers Dan Komunikasi Pembangunan. https://doi.org/10.46426/jp2kp. v23i2.104

Prianbodo, B. (2018). Pengaruh “TikTok" 
Mutia Rahmi Pratiwi, et al. The Identification of Persuasive Educational Message...

Terhadap Kreativitas Remaja Surabaya. Skripsi.

Putri, P. K. (2016). Aplikasi PendekatanPendekatan Persuasif Pada Riset Komunikasi Pemasaran: Iklan Melibatkan Penciptaan dan Penerimaan Pesan Komunikasi Persuasif Mengubah Perilaku Pembelian. Jurnal The Messenger. https://doi. org/10.26623/themessenger.v8i1.313

Riset: Ada 175,2 Juta Pengguna Internet di Indonesia. (2020). https://inet. detik.com/cyberlife/d-4907674/risetada-1752-juta-pengguna-internet-diindonesia

Rumata, V. M. (2017). ANALISIS ISI KUALITATIF TWITTER "\#TaxAmnesy" dan "\#AmnestiPajak." Jurnal Penelitian Komunikasi Dan Pembangunan. https://doi. org/10.31346/jpkp.v18i1.840

Saputra, R., Dhuatu, V. H., \& Chantiq. (2020). Pemanfaatan Aplikasi TikTok Sebagai Mood Booster (the Usage of TikTok App To Increase Mood Level). Indonesian Fun Science Journal.

Supriadi, Y., Drajat, M. S., Saleh, N. L., R., A. S., \& Huda, A. S. N. (2020). The Role of the West Java Indonesian Broadcasting Commission (KPID) in Preventing Citizen Panic Related to News and Information Regarding Covid-19. Mediator: Jurnal Komunikasi, 13(2), 167-177. https://doi.org/10.29313/ mediator.v13i2.6573

Sorrells, K., \& Sekimoto, S. (2016). Globalizing Intercultural Communication: A Reader. Sage Publication. https://doi.org/https:// www.doi.org/10.4135/9781483399164
Supratman, D. (2015). Dialog Dan Monolog Sebagai Unsur Persuasi Dalam Iklan. Jurnal Seni Rupa, 3(1), 19-26.

Susanti, Y., \& Yanti, F. (2020). Analisis Jenis Kalimat Imperatif Dalam Novel Matahari Karya Tere Liye. JURNAL KANSASI, 5(2).

Susilowati. (2018). Pemanfaatan Aplikasi TikTok Sebagai Personal Branding Di Instagram (Studi Deskriptif Kualitatif Pada Akun @bowo_allpennliebe). Jurnal Komunikasi.

Tosepu, Y. A. (2018). Media Baru Dalam Komunikasi Politik (Komunikasi Politik di Dunia Virtual). CV Jakad.

Wardhani, D. K., Susilorini, M. R., Angghita, L. J., \& Ismail, A. (2020). Edukasi Pencegahan Penularan COVID-19 Pada Anak Usia Dini Melalui Media Pembelajaran Audio Visual. Jurnal Abdidas, 1(3), 131-136. https://doi. org/10.31004/abdidas.v1i3.33

Wibowo, A. (2020). Hadapi COVID-19, Gugus Tugas dan TikTok Bersatu Dukung Tenaga Kesehatan. https:// covid19.go.id/p/berita/hadapi-covid19-gugus-tugas-dan-TikTok-bersatudukung-tenaga-kesehatan

\section{ACKNOWLEDGEMENT}

Thank you for the support that has been given by Dian Nuswantoro University, Mulawarman University, IAIN Pekalongan and Diponegoro University for the support that has been given in the form of morale and material so that it helps researchers significantly in completing research about The Identification of Persuasive Educational Message About Covid-19 Issue in TikTok. 